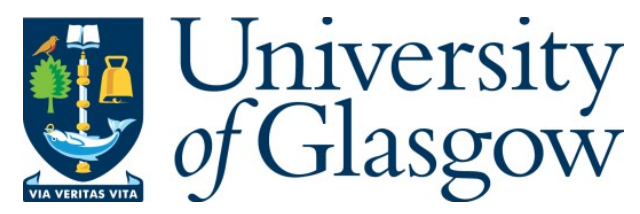

Goldman, J. (2020) Following Bradshaw and Bishop into Jacob's Room: British and Canadian editing strategies (tunnelling the textual hotspots, minding the gaps). Feminist Modernist Studies, 3(1), pp. 32-50.

(doi: 10.1080/24692921.2020.1718977)

This is the Author Accepted Manuscript.

There may be differences between this version and the published version. You are advised to consult the publisher's version if you wish to cite from it.

https://eprints.gla.ac.uk/207997/

Deposited on: 20 January 2020

Enlighten - Research publications by members of the University of Glasgow http://eprints.gla.ac.uk 


\title{
Following Bradshaw and Bishop into Jacob's Room: British and Canadian Editing Strategies (Tunnelling the Textual Hotspots, Minding the Gaps )
}

\author{
For however long these gossips sit, and however they stuff out their victims' \\ characters till they are swollen and tender as the livers of geese exposed to a hot fire, \\ they never come to a decision. \\ "That young man, Jacob Flanders," they would say, "so distinguished looking_-and \\ yet so awkward." Then they would apply themselves to Jacob and vacillate eternally \\ between the two extremes. He rode to hounds - after a fashion, for he hadn't a penny. \\ "Did you ever hear who his father was?" asked Julia Eliot. ${ }^{1}$
}

The pioneering editorial practices of Canadian Professor Edward Bishop and the late British Professor David Bradshaw offer distinct but complementary approaches to annotating Virginia Woolf's Jacob's Room (1922). Bishop, editor of the Shakespeare Head Jacob's Room (2004) and the holograph draft (1998), has gifted new modernist editing the hugely influential, crucial instruction 'Mind the gap!', 2 urging close attention to Woolf's spacing and lay-out of the material page as important literary signifiers. Has the magnificent, expansive landscape of Canada shaped perhaps Bishop's exquisite sense of textual space?

'Mind the word!' might well be the riposte of Bradshaw (1955-2016), who died before he could complete his Cambridge University Press edition of Jacob's Room, but left a body of scholarship pressing for attention to every passing cultural, material reference, not least in the numerous proper names of people, places, etc, populating Jacob's Room. Is there something peculiarly British in Bradshaw's obsessive pursuit of Woolf's literary onomastics? ${ }^{3}$ His methodology tunnels into Woolf's densely allusive, highly palimpsestic, writing, exposing centuries of British obsession with national, racial and class provenance, and with the 
correlating historical impositions of imperialist, patriarchal compulsory heterosexuality, and hetero-normativity.

How do we annotate (indeed should we annotate?) and how do we read the gaps Bishop points up not simply as blank fields? In relation to these, what are the hermeneutical ramifications of Bradshaw's onomastic and 'inter-textual hot spots'? ${ }^{4}$ Are British and NorthAmerican (editorial) nationalities really relevant? These questions have followed me through several years as a General Editor of the Cambridge University Press Edition of Virginia Woolf's Works, and in the last two years as co-author of the extensive Explanatory Notes for the forthcoming edition of Jacob's Room in that series. I have begun to understand the work of such editorial annotation as a version of that vacillation achieved by the gossips sitting mulling over Jacob's character in Jacob's Room, who 'however they stuff out their victims' characters till they are swollen and tender as the livers of geese exposed to a hot fire, they never come to a decision'. ${ }^{5}$ Similarly spurred to elucidate and fill out from the slenderest filaments of evidence in Woolf's richly yet elliptically constructed palimpsestic text, the Cambridge edition encourages the annotating editor 'to engage the reader in a process of informed exploration and interpretation that continues beyond the edition' and in the understanding that readers are 'accomplices in a process that can impose no finite interpretation on Woolf's writings'. ${ }^{6}$

And this process in turn is not unlike Woolf's famous cave-digging and tunnelling techniques, honed in 1923 while she was composing Mrs Dalloway (1925). Woolf writes in August 1923, ten months after the publication of Jacob's Room, of 'my discovery; how I dig out beautiful caves behind my characters; I think that gives exactly what I want; humanity, humour, depth. The idea is that the caves shall connect, \& each comes to daylight at the present moment — Dinner! ${ }^{17}$ By October 1923 Woolf is, 'now in the thick of the mad scene in Regents Park' of what becomes Mrs. Dalloway. In the published version of this scene, the 
war traumatised veteran Septimus Smith sees his comrade from the trenches, dead and in the same continuum as himself alive in the London park: 'There was his hand; there the dead. White things were assembling behind the railings opposite. But he dared not look. Evans was behind the railings!'8 Woolf continues her diary entry on this scene by commenting how 'it took me a year's groping to discover what I call my tunnelling process, by which I tell the past by instalments, as I have need of it. ${ }^{19}$ In the context of her writing on visions of the war dead, whose corpses were left in Flanders for burial, except for that of the unidentifiable 'Unknown Warrior', ${ }^{10}$ but who nevertheless haunt post-war London, Woolf's 'tunnelling method' seems redolent with the imagery of trench warfare. Tunnels 'were dug wherever trench systems developed during the Great War', and the war was also waged by some combatants beneath the surface of the battlefields in 'tunnels and subways, dugouts and galleries $[\ldots]$ eerie dangerous places to dwell', the grisly subterranean locus of 'what was one of the most veiled conflicts in the history of warfare'. ${ }^{11}$ These underground networks in Flanders, undermining and complicating the lines of the battle front between opposing nations, or fatherlands, are perhaps being reimagined by Woolf for narrative, feminist and pacifist, purposes. Woolf's tunnelling technique, furthermore, was already under way, I would like to suggest, in her stunning, darkly playful interlinked deployment of names in Jacob's Room. Tunnelling into that work with the editorial tools of both Bradshaw and Bishop yields some astonishing networks of multivalent signifiers linking lines of paternity with matters of nation and war. Bradshaw's attention to the very specificity of Woolf's words paradoxically returns us to Bishop's attention to gaps. And vice versa. It is Bradshaw's scholarship that is the main focus of this essay which chases down a cluster of the text's onomastic signifiers while simultaneously tunnelling into its ellipses, spaces and gaps in response to the questions of paternity, war and national destiny that hang over Jacob's Room: "'Did you ever hear who his father was?"'12 


\section{I: Bradshaw's Hotspots}

Following Bradshaw into Jacob's Room, the Cambridge edition has attended to every fictional character's name, and every other named person, including shop names and place names in the text. And as for the teemingly numerous characters of Jacob's Room, most readers, critics and editors simply trying to hold on to their names have grateful recourse to Mark Hussey's indispensable reference guide, Virginia Woolf: A-Z (1996) which lists 125 named fictional characters. ${ }^{13}$ While David Galef, using different criteria, goes further in his very helpful Appendix to The Supporting Cast: A Study of Flat and Minor Characters (1993) by listing all 'Named Characters' ('all animals and plants [...] arbitrarily excluded') and all 'unnamed characters, filed under their chief noun or identifying feature'. ${ }^{14}$ In so far as they can be counted, Galef lists at least 334 named characters from 'Achilles' to 'the brothers Zeno' ${ }^{15}$ and at least 568 citations of unnamed characters from 'an acrobat' to 'the growling of hundreds of work-people'. ${ }^{16}$ It is one thing to list them, quite another to gloss them. The Cambridge Jacob's Room is exceptionally densely annotated because the novel is so utterly densely allusive, and not least because it radically subverts expectations about any possible ranking of 'major' and 'minor' characters, and 'significant' or 'insignificant' events, locations and allusions. While its eponymous central character is largely absent, the text is then host to hundreds of named characters or unnamed characters with significant epithets (not to mention its numerous place names and multiple cultural, scientific, historical and political allusions). Bradshaw rightly alerts the reader to open a keen eye on the 'provocative ambiguities' of Jacob's Room, and in the annotations we have attempted to provide the reader with an informed openness to its myriad and multivalent signifiers.

In my contributions to the Explanatory Notes of the Cambridge Jacob's Room I found myself taking up Bradshaw's many inspirational leads, whilst also minding Bishop's gaps. My 
work therefore in a sense has a double paternity in Bishop and Bradshaw. The prompt of the Modernist Studies Association conference held in Toronto (2019) to frame papers in relation to the national and indigenous - "Making Modernism in/out of Canada" - in turn prompted thinking back through these Woolf's editorial fathers, so to speak, to the very questions of paternity and nation, or fatherland that the text of Jacob's Room plunges us into from its first page.

While Jacob Flanders's first name often goes unremarked upon (pace Heidi Stalla) ${ }^{17}$ most readers, critics and editors recognise his surname as proleptic of his fate in the Great War. Leaving aside his first name for the moment, let us attend to this elliptical protagonist's surname, then, while bearing in mind that in this extraordinarily populated work, Flanders is not the only proleptic nominal index of the Great War that will claim his life. The novel's opening and repeated, yet unspoken, questioning of his legitimacy as the son of Seabrook Flanders sets in motion a biting satire on how such matters of fatherhood and fatherland are at the heart of the darkness into which the Great War plunges every world citizen. The family surname is first invoked with the appearance of Jacob's mother, the widowed Betty Flanders. And everyone knows or thinks they know, even a hundred years later, what the name Flanders signifies. Flanders is, then, the ancient region of western Belgium which bore the brunt of the fighting in the Great War, and on maps the area traverses the French-Belgian border: 'Flanders was a synonym for death in battle', as Zwerdling points out, noting that 'nearly a third of the million British soldiers killed in World War I lost their lives in the Flanders mud. And the heaviest losses were among the young officers of Jacob's class' ${ }^{18}$ But Flanders as a location is in fact hardly settled or precise, and in the context of the Great War may denote locations in both France and Belgium, and more broadly the war itself. It was the poem 'In Flanders Fields' anonymously published in Punch magazine on 8 December 1915, 
by the Canadian army surgeon, Lieut.-Col. John McCrae (1872-1918), that quickly made this place name the most circulated synecdoche for the whole war itself:

In Flanders Fields the poppies blow

Between the crosses, row on row,

That mark our place; and in the sky

The larks, still bravely singing, fly

Scarce heard amid the guns below.

We are the Dead. Short days ago

We lived, felt dawn, saw sunset glow,

Loved, and were loved, and now we lie

In Flanders fields.

Take up our quarrel with the foe:

To you from failing hands we throw

The torch; be yours to hold it high.

If ye break faith with us who die

We shall not sleep, though poppies grow

In Flanders fields. ${ }^{19}$

Flanders then is also a lyric, textual place or space. The Cambridge edition's 'Explanatory Note' on the name 'Flanders' points out how this poem which became so extraordinarily $\operatorname{popular}^{20}$ primarily commemorates the second Battle of Ypres in the spring of 1915, and was the inspiration behind the adoption in 1921 of the scarlet corn poppy (Popaver rhoeas) which grows when the ground has been churned up and all other plants are dead-as the symbol for Remembrance Day. We point to Jacob's 'Greek dictionary with the petals of 
poppies pressed to silk between the pages'. ${ }^{21}$ But we also point up how the surname may also echo Moll Flanders by Daniel Defoe (1660?-1731), published 200 years before Jacob's Room in $1722 .{ }^{22}$

If Flanders is multivalent in terms of its possible cultural, political, and geographical reach, Woolf's novel soon has us worrying over just how securely or legitimately attached it is as surname to the protagonist and his brothers:

Betty Flanders was romantic about Archer and tender about John; she was unreasonably irritated by Jacob's clumsiness in the house.

Captain Barfoot liked him best of the boys; but as for saying why ... (VW's ellipses $)^{23}$

The ellipses here, like the random gaps that fissure the pages, are places in the novel where the reader may feel obliged to do some tunnelling behind or below what is actually uttered and printed on the page. Bradshaw, in Winking , Buzzing, Carpet-Beating: Reading Jacob's Room (2003), gives a brilliant reading of the innuendo at play in Jacob's Room from its very first page, and he makes a convincing case for questioning the paternity of the baby Johnny, given that Mrs Flanders's dead husband is, the reader gathers, unlikely to have been the father: 'Mrs. Flanders had been a widow for these two years' ${ }^{24}$ Without spelling it out, Woolf's text invites the reader, busy accumulating information on the precise circumstances of the widowed and nursing mother Betty writing from Cornwall ("there was nothing for it but to leave" $)^{25}$ to the married Captain Barfoot back in her home town Scarborough hundreds of miles away, to do the math.

My research confirms and expands on Bradshaw's findings concerning Jacob's parentagethe gaps in his family tree-and key locations (Scarborough and Cornwall), demonstrating how they are further played out in fascinating concrete detail in shimmering and elliptical networks of multivalent textual tunnels as precarious and shocking as those actually dug by 
soldiers at the front. Bradshaw superbly demonstrates his own axiom that 'a reader of Jacob's Room who is not asking questions from the beginning of the novel is not really reading Jacob's Room' ${ }^{26}$ And he identifies many contradictory innuendos surrounding Jacob's paternity: 'Jacob conjectures that "old Barfoot is talking to my mother. That's an odd affair to be sure". To be sure it is', says Bradshaw: 'The Captain's weekly visits to Mrs Flanders create disquiet in the mind of Ellen Barfoot and they should also give the reader much food for thought'. ${ }^{27}$ How might a supplier of Explanatory Notes also 'tune in to this innuendo'? Bradshaw alerts us to the perils of 'turn[ing] an entirely deaf ear to it', ${ }^{28}$ and to the rewards of paying close attention to the historical, political and cultural valences of every passing name in a novel teeming with names.

If Jacob Flanders's surname is proleptic of his fate in the Great War, then we must accept from the outset, that this novel therefore has no fidelity to unities of time or place. Furthermore as it begins with a self-reflexive scene of writing (a snatch of Betty Flanders's letter from Cornwall to Scarborough) where a full stop dissolves into a comma courtesy of its author's tears, the reader is encouraged from the outset to a adopt a radical hermeneutics of suspicion, that is to 'tune in' to the innuendo and to tunnel. If Jacob Flanders's surname gives us pause, then, we also need to 'tune in' to the literary onomastics at play in all the other names in the work, not least of the two men presented as contenders for his and his brothers' paternity: Seabrook Flanders and Captain Barfoot.

I have traced the name of his possible legitimate father, Seabrook Flanders, to a British military procurement firm supplying lorries to the Great War, and the name of his equally possible illegitimate father to a philanderer suspected of impregnating a married woman in a Victorian novel reviewed by Woolf. The Cambridge Jacob's Room's 'Explanatory Notes' record all this without ranking or interpretation, respecting Woolf's multivalent textual 
dialogism. Like the gossips in the novel, attentive tuned-in readers of Jacob's Room 'never come to a decision'. ${ }^{29}$

\section{Captain Barfoot}

At first named 'Captain Bingham' in the draft, ${ }^{30}$ Captain Barfoot is a fascinating and complex textual hotspot. Both 'Captain' and 'Barfoot', which is an unusual surname, merit scrutiny and some explanations. The latter is the "nickname for someone who was in the habit of going about his business unshod', ${ }^{31}$ and ' Barfoot may be an ironically oblique version of Oedipus, whose Greek name of "swollen foot" reflects the bar driven through his feet. ${ }^{32}$ But we might also attend to the information given later concerning Barfoot's 'rubber-shod stick-for he was lame [...] having served his country', ${ }^{33}$ which also touches on his captaincy. He served, it is implied, in the navy of the British Empire, perhaps in deployment to India. And there is a connection to be drawn between serving the nation and the maiming and severance of limbs as well as the product of rubber. Compare, for example, Colonel Abel Pargiter, who 'had lost two fingers of the right hand in the Mutiny'. ${ }^{34}$ Woolf herself wrote, in February 1921, about the return of peace with reference to these constellating images: 'there are very few wounded soldiers abroad in blue, though stiff legs, single legs, sticks shod with rubber, \& empty sleeves are common enough' ${ }^{35}$ It is also worth noting, and tunnelling back to earlier wars too: the War of American Independence (1775-83) and wars against the French (1793-1815). And Jacob's Room bristles with allusions to the latter in its running tropes on the Duke of Wellington and the Battle of Waterloo, itself fought in Flanders, and its centenary commemorated during the Great War fought of course over the same terrain, albeit with the French and English as allies. ${ }^{36}$ In both earlier wars there were numerous Invalid Companies established which 'formed the core of coast-artillery at home', because in the eighteenth century 'a man enlisted in the Royal Artillery for life', and those who were 'unfit to stand up 
to the rigours of active service' found themselves in Invalid Companies. ${ }^{37}$ The Invalid Companies were disbanded in 1819 and replaced by the Invalid Detachment which grew in numbers throughout the nineteenth century and were abolished in 1859. They served under the Mast Gunner at every coast-defence in Britain. In 1824, for example, there were three such Invalids at Scarborough Castle, serving under Master-Gunner Robert Purcell. ${ }^{38}$ So the lame Captain Barfoot's service to his country is over in Jacob's Room, whereas in an earlier era he would perhaps still have served as one 'not in their first youth or partially disabled' routinely redeployed to coast-forts, such as Scarborough.

Rubber was a ubiquitous product (for example, pneumatic car and bicycle tyres). Furthermore, as Bradshaw points out apropos James Joyce's Dubliners (1914), anything rubber-shod would in the early twentieth-century evoke the horrors of the Congo Free State and the rubber that was extracted from that blighted territory without pity or restraint between the early 1890 s and the State's enforced annexation by Belgium in 1908 in the face of concerted international outrage. [...] By around 1913 the rubber plantations of Ceylon, Singapore, and Malaya were beginning to come into full production and the wild latex-bearing trees of the Congo Free State had been all but destroyed, but during the opening decade of the twentieth century $[\ldots]$ they were being exploited to obliteration and the ghastly plight of those held as slave labour in their devastation was continually and sensationally in the news. ${ }^{39}$

Bradshaw points up 'a discourse of contraception' behind James Joyce's rubber tropes ${ }^{40}$ and this we might well apply too to the 'rubber-shod stick' of Captain Barfoot who may be conducting a sexual liaison with Mrs Flanders: "'Odd she don't marry again!" "There's Captain Barfoot to be sure"'. ${ }^{41}$ Betty, according to one critic, 'may be content with the town's knowledge of the company she keeps with Barfoot because it prevents additional suitors from 
coming forward, and Barfoot's lameness may symbolize the limited range of activities between them'. ${ }^{42}$ The innuendo laden allusion to 'his rubber-shod stick', on the other hand may point to the limited effectiveness of their choice of prophylactics. And if 'rubber-shod stick' is an allusion to contraceptives then 'having served his country' may be an equally bawdy allusion to sexual intercourse, as well as to a discourse of national eugenics and breeding. Woolf's Bloomsbury colleague, E.M. Forster makes similar allusion and innuendo in Howards End (1910) concerning Henry Wilcox whose work is in "'rubber-it is a big business" and his office 'the Imperial and West African Rubber Company'. ${ }^{43}$ Readers of Jacob's Room, then, as Bradshaw observes of readers of Howards End, would know that rubber was 'a deeply tainted commodity'. ${ }^{44}$ Rubber condoms were used not only for contraceptive purposes but also to protect against venereal diseases, and by 1860 were 'produced on a large scale; the major benefit was that they could be reused and could be afforded at a cheaper price' and 'were made to size originally'. ${ }^{45}$ If Barfoot's failed condom was responsible for the conception of Jacob and/or any of his brothers, then how ironic that Jacob himself once at war, would be without such a thing. Whereas the Great War 'saw the deployment of condoms, along with weapons and ammunition for the German army', the 'American and British armies did not use condoms, even having known their ability to help prevent venereal diseases' and the result was 'a mass amount of soldiers with syphilis and gonorrhea'. ${ }^{46}$

Bradshaw's important work on the textual instability of Jacob's Room in relation to rumour and innuendo concerning Jacob's paternity, along with his work elsewhere on rubber combine most productively to serve the Cambridge edition's 'Explanatory Notes' about Captain Barfoot. And my further research into the surname Barfoot has supplemented this material in fascinating ways. It may be linked, I suggest, to the journalist, prolific author, and ghost writer, Samuel Levy Bensusan, who came from a prominent Sephardic Jewish family, 
and became famous as the champion of mistreated animals in 1896. His writings were much admired by 'peers such as Hardy, Wells, and Kipling'. He became infamous over his scandalous 'liaison with a Miss Fanny Barfoot,' according to the $O D N B$. The fruit of this liason was a son born to Fanny Barfoot on 14 December 1900. Bensusan who accepted responsibility for the care and education of 'the boy' became 'the agricultural correspondent for the New Statesman ${ }^{\prime 47}$ to which Leonard Woolf was also a regular contributor. Captain Barfoot also shares the surname of a family of characters in George Gissing's popular novel, The Odd Women (1893), reviewed by Woolf for the $T L S$ in $1912 .{ }^{48}$ Miss Mary Barfoot, who trains up young women to be secretaries, 'bore herself as the lady of aristocratic tastes, as a genial woman of the world, or as a fervid prophetess of female emancipation [...] Yet Mary Barfoot had known many troubles, poverty among them.'49 Her '"impudent"' cousin is Everard Barfoot, who "'went to Eton, and the school had a remarkable effect upon him; it made him a furious Radical. Instead of imitating the young aristocrats he hated and scorned them."'50 He is a philanderer, wrongfully alleged to have had an affair with and impregnated a married woman who is in fact in a relationship with Barfoot's neighbour, and pregnant by her subsequently estranged husband. On returning to England from Ireland, by chance at the same time as 'the arrival from Madeira of Mr. and Mrs. Thomas Barfoot', Everard visits this brother, 'who for the present was staying at Torquay', Devon. His philandering is described thus:

Everard Barfoot's advances surprised her not a little. Judging him as a man wholly without principle, she supposed at first that this was merely his way with all women, and resented it as impertinence. But even then she did not dislike the show of homage; what her mind regarded with disdain, her heart was all but willing to feed upon, after its long hunger. Barfoot interested her, and not the less because of his evil reputation. Here was one of the men for whom women - doubtless more than one- 
had sacrificed themselves; she could not but regard him with sexual curiosity. And her interest grew, her curiosity was more haunting, as their acquaintance became a sort of friendship; she found that her moral disapprobation wavered, or was altogether forgotten..$^{51}$

Bradshaw's reading of Captain Barfoot's implied but never proved illicit paternity (achieved by Bradshaw without the benefit of this possible allusion to Gissing's Everard Barfoot and his rumoured illicit paternity) is strengthened:

If Seabrook Flanders is not Johnny's father, who is? Captain Barfoot, the man to whom Mrs Flanders writes 'many-paged, tear-stained' letters [...] the man who calls on her 'every Wednesday regular as clockwork, and never brings his wife. Just after being given this detail, we are told that [his] attentions [...] 'ripened Betty Flanders, enlarged her figure' [Bradshaw's emphasis], and such verbs seem deliberately designed to lure the reader into thinking of him as Johnny's biological father. ${ }^{52}$ Unlike Gissing, and the gossips, Woolf pointedly does not settle the matter.

\section{Seabrook Flanders}

Jacob's father is only ever referred to by his very unusual forename, which occurs seven times in Jacob's Room, and he is never referred to as 'Seabrook Flanders', which readers must construe for themselves, from the example of 'Betty Flanders', who is only occasionally 'Betty'. In the early draft he is 'Seabrooke'. ${ }^{53}$ Here are some of the valences for that name: Seabrook is a small coastal village in Kent that lies between Sandgate and Hythe near Folkestone. The Royal Military Canal starts here, running for 28 miles to Cliff End near Hastings, following the old cliff line bordering Romney Marsh; it was constructed as a defence against possible invasion during the Napoleonic Wars (1803-15). The Woolfs' library contains Modern Fruit Growing, 2nd edn, by William Pertwee Seabrook (1919), ${ }^{54}$ but 
the name does not occur anywhere else in Woolf's writings. Seabrook Lodge School was a preparatory school in Hythe, Kent. The actress Kate Vaughan (1852?-1903) played Kitty Seabrook in Arthur Branscombe's popular 'extravaganza' burlesque show, King Kodak at Terry's Theatre, in the West End, London (1894). The American occultist and journalist, William Seabrook (1884-1945), who became a reporter for the New York Times in 1917, had been gassed at Verdun in 1916 while serving with the American Ambulance Field Service of the French Army and awarded the Croix de Guerre. He was a friend of Aleister Crowley who stayed with him on his farm in 1919. In 1917 he published Diary of Section VIII, detailing his war service.

But a more culturally prominent linking of the names Seabrook and Flanders is available, if indeed, Jacob's father's first name, like his surname is also understood to be a proleptic reference to the Great War, in that Seabrook was the London manufacturer of lorries procured by the War Office for use at the front, as reported in a prominent illustrated advertising notice in The Times, 10 September 1915, under the heading 'Seabrook' in very large typeface: 'Over in Flanders, at certain hours on a certain official time-table, a long line of motor lorries ploughs along the ruined roads, taking rations from rail-head to the troops. [...] They are Seabrook three-tonners, chosen by the War Office for the serious business of war' and having 'proved themselves capable of standing the terrific stress of war service', the Seabrook Brothers assure, they will 'give the same satisfaction here as in Flanders. ${ }^{55}$ A week later a similar illustrated advertisement includes a testimonial from 'Driver, M.T., A.S.C., British Expeditionary Force', prompting the conclusion: 'That's what the drivers think of 'Seabrook', and who knows if they don't./ Seabrook lorries are perfect over the ruined roads of ravished Flanders, they work to a time table, day after day, week after week. ${ }^{156}$ Here, the illustrated lorry bears the name 'Clifford and Seabrooks' again advertised as the 'Seabrook 
Lorry' in The Times a month later under that name but still with Seabrook in prominent large typeface..$^{57}$

In one sense, what does it matter who Jacob Flanders's father was? Either way, he still ends up dead. But in another, the unsettled matter of his paternity, and the question of his legitimacy, particularly in light of the valences of Seabrook Flanders's name, prompts readers to consider the cost of his legitimation by a father whose first name and surname combine to signify the culturally prominent name of military procurement firm supplying lorries to the Great War that claims the life of his own son. Is it really so much more scandalous to be the illegitimate son of a pleasure-seeking philanderer?

\section{II: Bishop's Gaps}

Bishop, in his superb essay 'Mind the Gap: The Spaces in Jacob's Room' (2004), points up the novel's plenitude of 'fissures, ruptures, gaps, and chasms ${ }^{158}$ to which the reader must attend as carefully as the words into which they intervene. Many of these gaps drive channels between national locations, not least the following very noticeable four-line blank space made by Woolf when she moves the narrative from the episode where night falls in Greece to a night scene back in England:

The sound spread itself flat, and then went tunnelling its way with fitful explosions among the channels of the islands.

Darkness drops like a knife over Greece.

[space intentional in WOOLF'S ORIGINAL edition] 
"The guns?" said Betty Flanders, half asleep, getting out of bed and going to the window, which was decorated with a fringe of dark leaves.

"Not at this distance," she thought. "It is the sea."

Again, far away, she heard the dull sound, as if nocturnal women were beating great carpets. There was Morty lost, and Seabrook dead; her sons fighting for their country. But were the chickens safe? Was that some one moving downstairs? Rebecca with the toothache? No. The nocturnal women were beating great carpets. Her hens shifted slightly on their perches. ${ }^{59}$

Commenting on that ominous performative utterance that seems to blacken the white space intervening in the first British edition — but not the American—between Jacob in Greece and his mother in Britain, Bishop observes: 'when war enters the text- the war that will kill Jacob - the four line gap in the English edition leaves the line hanging, letting the ominousness of the metaphor (however cliched the phrase 'drops like a knife' might be) emerge fully. ${ }^{160}$ The Canadian editor's attention to the difference between English and American editions prompts further consideration, I would add, of the status of that lost, closed up gap which North American readers could only know about with access to the English edition, and vice versa. Bishop's Shakespeare Head edition of Jacob's Room (2004) 'restores' Woolf's 'intended' gaps, yet the closed gaps of the first American edition (published a few months later) of course remain closed for many readers in North America. ${ }^{61}$ Paying attention to the national signifiers on either side of the English edition's gap and to the lack of a gap between them in the American edition prompts us further to reflect on the cliché of sudden darkness that Bishop points up, reminiscent as it is of British Foreign Secretary Sir Edward Grey's famous remark on the eve of Britain's entry into the Great War in August 1914: 'The lamps are going out all over Europe, we shall not see them lit again in our life-time'. ${ }^{62}$ The channel between the European continent and Britain that opens in the British edition is closed up for the American 
reader, on whom such a differential is perhaps lost if thinking of Europe as an homogenous mass over the Atlantic, one that includes Greece and Britain in a continuum. Perhaps the (closed) gap further suggests a point in the war when the darkness had yet to drop on America, at least until 6 April 1917.

This carpet-beating passage on the English side of this textual gap, is discussed by Bradshaw as 'a clear allusion to the December 1914 bombardment of Scarborough', ${ }^{63}$ is further examined along with gap above it, by Patrizia Muscogiuri in relation to Woolf's 1916 essay for The Times, 'Heard on Downs' (1916): ${ }^{64}$

Published $[\ldots]$ at a time when state censorship had already silenced some of her intellectual friends like Clive Bell and Bertrand Russell - and signed 'from a correspondent', the article develops a satirical hybrid form combining reportage, experiential narrative, allusions to classical mythology, the gothic and rural anecdotes to target and undermine the fatalistic rhetoric of the discourse of war and, more subtly, the restrictions on information underlying it, treating blind nationalist faith on a par with popular misbeliefs, namely as 'myth', both products of deliberate state disinformation. ${ }^{65}$

Thinking of war-time censorship and disinformation Muscogiuri's reading has the English Channel of the essay become another kind of blank, and one that may inform that textual gap intervening in the novel between the Greek episode and the English episode. The location of the latter in the novel is however Scarborough on the east coast overlooking the North Sea (itself known as the German Ocean until the outbreak of the war). ${ }^{66}$ What bafflingly multiple semantic confluences flood into this textual gap, this no-man's land, distorting coastlines confusing oceans and national boundaries. Woolf's satire, as both Bishop and Bradshaw demonstrate too, is thus available as an anti-nationalist, or inter-nationalist, trans-nationalist parody of war-time disinformation strategies. The novel buttonholes attentive transatlantic 
readers, then, to consider what presumptions of national identity we bring to its pages (words and blank spaces), and not only British, European, Canadian or North American. Implicit here is a concept of nationlessness too that anticipates Woolf's feminist pacifist declaration in Three Guineas (1938): 'as a woman, I have no country. As a woman I want no country. As a woman my country is the whole world'. ${ }^{67}$

\section{Conclusion: Catching Names, Minding Gaps}

"Are you going away for Christmas?" said Mr. Calthorp.

"If my brother gets his leave," said Miss Edwards.

"What regiment is he in?" said Mr. Calthorp.

"The Twentieth Hussars," said Miss Edwards.

"Perhaps he knows my brother?" said Mr. Calthorp.

"I am afraid I did not catch your name," said Miss Edwards.

"Calthorp," said Mr. Calthorp. ${ }^{68}$

Almost a stanza of percussive poetry, this staccato dialogue between two passing characters in Jacob's Room must have seemed a familiar one to its first readers so soon after the war. On top of that is the self-reflexiveness of the exchange in which the observation '"I am afraid I did not catch your name,"' serves as a reminder to the reader precisely to pay attention and catch the name. How quickly and fixedly do estimations of character form around the telegraphic exchanging of a name. How sure are we, for instance, of the composite, fictive, Jacob Flanders's nationality, ethnicity, race? His possibly Dutch/Belgian surname aside, some find in him aspects of Woolf's friend the British war dead poet, Rupert Brooke (1887-1915) whose poem 'The Soldier' (1915) has become a clichéd paeon to English national sacrifice in the Great War; or her own brother, Thoby Stephen (1880-1906), dead long before the Great War but doubtless facing conscription had he lived. But, following Heidi Stella's excellent 
response to her own question, 'Is Jacob Jewish?', ${ }^{69}$ let us consider the Biblical allusions in Jacob Flanders's first name and in the novel's title, which clearly nudges us to think of Jacob's Ladder. Why is it Room and not Ladder? Remember too the Biblical Jacob's brother Esau whose birth-right Jacob the trickster assumes. Jewishness in the anti-Semitic era of the Great War signified statelessness as well as internationalism. Perhaps the Jew becomes a signifier for citizenship of the implicit no-man's land in those gaps and fissures and channels between all those wordy signifiers of nation, father state and fatherhood, that open in Jacob's Room. And we might for a possible, partial model for Jacob look not only to Leonard Woolf, who attended Cambridge like Jacob, but also to his brothers, Cecil Woolf and Philip Woolf. If we had paid attention to the dialogue above between Miss Edwards and Mr Calthorp and caught their passing common point of reference to each having a brother in the Twentieth Hussars we would soon be tunnelling towards these two Woolf brothers.

Virginia Woolf's brother-in-law Cecil Woolf(1887-1917)—whose dates, education and early career in law before joining up match Jacob's — attended St Paul's School on a scholarship; went in 1906 to Sydney Sussex College, Cambridge; then held a history fellowship at Trinity College, Cambridge; then became a lecturer at the London School of Economics. His prize-winning dissertation on Medieval Political Thought was published by Cambridge University Press in 1913. He and his brother Philip Sidney Woolf published their translation of Stendhal's (1783-1842) De l'amour (1822) in 1915 with Virginia Woolf's halfbrother Gerald Duckworth. Philip gave up Sidney Sussex College, Cambridge 'to become a painter, and he was at the Heatherley School of Art when the war broke out' ${ }^{70}$ Philip and Cecil joined the Twentieth Hussars, and were both injured by the same shell in the Battle of Cambrai in November 1917, Cecil dying shortly after. The Cambridge edition's 'Explanatory Note' on the passing reference to the Twentieth Hussars includes the following observations. 
The Twentieth Hussars was a cavalry regiment, which when war broke out 'were stationed at Colchester [...] In November 1917 they were dismounted to take part in the Battle of Cambrai, which became famous as an attack that 'was carried out very largely by the use of tanks on a big scale'. ${ }^{71}$ We give details of the fates of Leonard Woolf's brothers Cecil and Philip at Cambrai and of Virginia Woolf's diary entries on receipt of the news, including her marked interest in the progress and experiences of her husband's brothers in the army, for example, in her attention to how both were 'entirely sick of the army', continuing: 'Nevertheless, Cecil thinks of being a permanent soldier, because the life is better than a Barrister's life'. ${ }^{72}$ Leonard's brothers' military life was a fate which he himself was spared (his tremor pre-empting the need to declare his conscientious objection). Virginia had already recorded her forebodings:

Cecil has a machine gun, which may lead to his going [to the front], \&, if so, almost certainly to his being killed. Poor Philip was a good deal agitated, I thought, with his prospects. What is he to do after the war is over? He thinks he must emigrate. Cecil would like to stay on in the Army, which, however, one can't do, unless one has money, \& neither of them has a penny. Five hundred a year is considerably more valuable than beauty or rank. ${ }^{73}$

Having been briefly recalled to the front, Philip after the war and following a short stint in India, became an estate manager for the Rothschild family. ${ }^{74}$ Virginia saw that the two brothers 'had always done everything together and I don't know how he'll get on alone';75 and Leonard later described them as enjoying 'a David and Jonathan affection' ${ }^{76}$ — we might think of the Biblical Jacob and Esau too.

In 1918 Woolf helped the 'pretty wretched'77 convalescing Philip (in Fishmongers' Hall hospital) to set the type for the slim volume of Cecil Woolf's poems the Hogarth Press published in $1918,{ }^{78}$ its second ever publication [...] since 'giving him occupation it would be 
a good thing to do', although he was 'obviously very wretched; has no future wishes evidently, save to get out to France'. ${ }^{79}$ On 'setting up Cecil's poems' for the press she concludes: 'They're not good; they show the Woolf tendency to denunciation, without the vigour of my particular Woolf. I had all sorts of accidents \& only finished one' ${ }^{80}$ The volume was briefly and anonymously reviewed in the $T L S$ on 23 January 1919 (a review I was able to share last year with Cecil Woolf's namesake, Phillip's son, and Leonard's nephew, not long before he died, and whose memorial was in London the same week-end as the Toronto MSA conference where I gave a version of this essay). Cecil Woolf's poetry is reviewed here along with poetry volumes by George Rostrevor, A. H. Sidgwick, and Arthur Lewis Jenkins, under the heading 'Four Young Poets'. ${ }^{81}$ The anonymous review (later disclosed as by Harold Child) opens by blessing 'the striving and crying of the most modern poetry, because, in Goethe's phrase, each step that it takes is a step as well as a goal. The poet may be presumed to have achieved the effect he attempted; he has, at any rate, placed another rung in a Jacob's ladder that may some day lead to unimagined heavens of poetic beauty' ${ }^{82}$ How moving to find this co-opting for poetry of the Biblical 'Jacob's Ladder', and in the context of a review of the poems of Woolf's brother-in-law snuffed out in the war before he could ascend to higher rungs of lyric achievement. And how the words of this review set us tunnelling back into Jacob's Room, looking anew for further intertexts. Jenkins like Cecil Woolf was 'killed in the war', and the reviewer finds he 'lived long enough to die a poet'. Likewise, he continues: 'Mr. Woolf, too, had the spark of poetry in him. "He loved Learning and Art well," says a note in this privately printed little volume, "but men and horses better." We wish that he had written a poem or two about horses $[\ldots]^{\prime} .{ }^{83}$

This latter observation, which subtly plays on the name Philip which comes from the Greek $\Phi 1 \lambda \imath \pi \pi \circ \varsigma$ meaning friend of horses, has me racing back to both Jacob's Room and to Bradshaw's lecture where he points up the novel's notable equine tropes, not least in relation 
to Wellington and the image of the funereal riderless horse ${ }^{84}$ Building on the findings of Susan Bennett Smith, Bradshaw uncovers Woolf's anti-militarism at play in her 'subversive tilt at Wellington' in the scene in Hyde Park near the statue of Achilles commemorating the Iron Duke: 85 "''This statue was erected by the women of England..."' Clara read out with a foolish little laugh. "Oh, Mr. Bowley! Oh!" Gallop—gallop—gallop—a horse galloped past without a rider. The stirrups swung; the pebbles spurted. ${ }^{186}$ Both Clara and Julia spot this 'horse gallop[ing] past without a rider'. One possible historical provenance of this riderless horse tracked by Bradshaw leads to an ancient military tradition observed at Wellington's funeral when his groom led his horse from whose sides hung reversed the Duke's empty boots. ${ }^{87}$ His mordant aside on its possible significance in Jacob's Room is itself both Woolfian and Bradshavian in its glancing call to liberty: 'The horse, moreover, unlike so many of the characters in the novel, has momentarily escaped England's all-enveloping culture of "discipline" and restraint. ${ }^{, 88}$ The horse, free of the rider and his empty boots, it seems, is a Woolfian trope of dissent from what Bradshaw elsewhere calls 'the necrolatry of the state' ${ }^{89}$ Tunnelling from this submerged allusion to Wellington's empty boots, unearthed from the text by Bradshaw, to the closing vignette of Jacob's mother holding 'out a pair of Jacob's old shoes', ${ }^{90}$ the reader is now presented with divergent and multiple valences. This gesture focusing on the war dead Jacob's empty civilian shoes may be read, for example, as a symbol of individual maternal loss and a pacifist indictment of the war that took the life of their wearer. But is this troping on vacated footwear also signifying deference by this same bereaved mother (or over her head by the text itself) to a form of patriotic war commemoration, one in keeping with the emptiness of Wellingtonian state necrolatry? Those readers not 'tuned in' to the running satire on the Duke might think so. Or, taking a cue from the vision of the galloping riderless horse bolting from the Iron Duke's commemorative statue, rather than dwelling on the already doomed and war slaughtered former occupant of 
the shoes, we might instead look for the living escaped horse no longer saddled between them. Consider too the civilian Jacob's participation in the hunt in Chapter Nine as he 'galloped over the fields of Essex' with his aristocratic hosts:

A few moments before a horse jumps it slows, sidles, gathers itself together, goes up like a monster wave, and pitches down on the further side. Hedges and sky swoop in a semicircle. Then as if your own body ran into the horse's body and it was your own forelegs grown with his that sprang, rushing through the air you go, the ground resilient, bodies a mass of muscles, yet you have command too, upright stillness, eyes accurately judging. Then the curves cease, changing to downright hammer strokes, which jar; and you draw up with a jolt; sitting back a little, sparkling, tingling, glazed with ice over pounding arteries, gasping: "Ah! ho! Hah!" the steam going up from the horses as they jostle together at the cross-roads, where the signpost is, and the woman in the apron stands and stares at the doorway. The man raises himself from the cabbages to stare too.

Here the human rider so dominates the horse beneath him it seems to merge with his own body ('your own body ran into the horse's body and it was your own forelegs grown with his that sprang') in this spectacle of class privilege astonishing the serving woman and the labouring man. But Woolf's self-reflexive writing here seems to underline itself to the reader as a significantly equine textual hotspot: 'the horses as they jostle together at the cross-roads, where the signpost is'. Is this signpost at the cross-roads prompting the reader to choose a direction of reading? Should we perhaps dismount?

And now these equine tropes must be considered in relation to the horseless riders of the Twentieth Hussars, who found themselves dismounted and in the trenches for the Battle of Cambrai, and of course to the Hussars own now riderless horses. The escaping horse in Jacob's Room may be a horse in pursuit of a poet, Woolf's elegiac tribute to the lost equine 
lyric that might have constituted that 'next rung in a Jacob's ladder [...] to unimagined heavens of poetic beauty', had her brother-in-law survived. Jacob's 'Room' is close to Jacob's 'Ladder' not only via the near homophone Jacob's 'Rung' but also via the hidden pun on the Italian 'Stanza' which returns us to the review of Cecil Woolf's poems (Cecil's stanzas). Cecil Woolf's poems are not 'war poems', the reviewer notes, but he singles out and reproduces the dead poet's 'best achievement', a sonnet, 'written in 1909, but apposite now:- // 'I think of one, dead in a lonely place $[\ldots]^{191}$

This is not at all to suggest that when we think of Jacob and his empty shoes we too must only 'think of one, dead in a lonely place' (whether Thoby Stephen, Rupert Brooke, Cecil Woolf, The Unknown Warrior, or the Duke of Wellington), for we must surely think too of the image of how the 'carters, jamming the brakes down, pulled their horses sharp up' immediately preceding the closing lyric (elegiac) cry of a 'harsh and unhappy voice cried something unintelligible'. ${ }^{92}$ Who is to say this is not an equine voice? And when we read how Bonamy cried "'Jacob! Jacob!"', we are returned to the opening and broken refrain from his childhood on the beach: "'Ja—cob! Ja—cob!" Archer shouted'93 looking for his lost brother, whereby the second syllable 'cob' in one reading is equine (a small stout horse) — in another it is testicular - and the first syllable 'Ja' suggests, among other things, the German for yes. ${ }^{94}$ Archer's breaking open a gap in the name, represented by the long em dash, does Jacob a textual violence which is possibly, like his surname, proleptic of his fate in Flanders. Yet that severance also liberates in the same broken name an escaping affirmative lyric horse! The grieving Bonamy, on the other hand, sutures the syllables together again, as if pulling 'horses sharp up', as if 'Ja — cob' is finally broken in, kept in harness, even or especially in futile death. Even when we attempt to utter his first name, then, uncoupled from the surname Flanders, it is impossible for readers and editors at such a cross-roads to think of the sign 
'Jacob' or 'Ja— cob' as 'simply one thing', ${ }^{95}$ human, or horse. Rather we 'vacillate eternally', like the gossips.

\section{BIBLIOGRAPHY}

Anon., "Waterloo Re-Fought On The Cinematograph", The Times, 9 July 1913, 11.

Anon., 'Waterloo Day', The Times, 18 June 1915, 9.

Anon, 'Seabrook, The Times, 10 September 1915, 10.

Anon, 'Seabrook Motor Lorries', The Times, 14 Sept. 1915, 4.

Anon, 'Clifford', The Times, 21 October 1915, 5.

Barton, Peter, Peter Doyle, and Johan Vandewalle, Beneath Flanders Fields: The Tunnellers War 1914-1918, Stroud: The History Press, 2010.

Bishop, Edward L., 'Mind the Gap: The Spaces in Jacob's Room', Woolf Studies Annual, 10 (2004), 31-49.

Bradshaw, David, “'Vanished Like Leaves': The Military, Elegy and Italy in Mrs. Dalloway', Woolf Studies Annual, 8 (2002), 107-25.

Bradshaw, David, Winking, Buzzing, Carpet-Beating: Reading 'Jacob's Room', Southport: Virginia Woolf Society of Great Britain, 2003.

Bradshaw, David, 'Howards End', in The Cambridge Companion to E. M. Forster, ed. David Bradshaw, Cambridge: Cambridge University Press, 2007, 151-72.

Bradshaw, David, “"Perished Alive": Dubliners and the Reek of Rubber', Essays in Criticism, 67:1 (January 2017), 20-36.

[Child, Harold Hannyngton] (1919), 'Four Young Poets', TLS (23 January), 40.

Darling, J.C., 20th Hussars in the Great War, Lyndhurst: J.C. Darling, 1923.

Forster, E.M., Howards End, London: Edward Arnold, 1910.

Fussell, Paul, The Great War and Modern Memory, London: Oxford University Press, 1977. 
Galef, David, The Supporting Cast: A Study of Flat and Minor Characters, University Park, PA: Pennsylvania State University Press, 1993.

Gissing, George, The Odd Women 3 vols. (London: Lawrence \& Bullen, 1893.

Goldman, Jane, Susan Sellers, and Bryony Randall, 'General Editors' Preface', Orlando: A Biography, ed. Suzanne Raitt and Ian Blyth, Cambridge: Cambridge University Press, 2018.

Goldman, Jane, “"Her-it—age!”: Virginia Woolf and Syllabic intervention-Or, "Heritage" is a Kim Novak word', Virginia Woolf and Heritage: Selected Papers from the Twenty-sixth Annual International Conference on Virginia Woolf, ed. Jane de Gay, Tom Breckin and Anne Reus, Clemson, SC: Clemson University Press, 2017.

Grey, Viscount, of Fallodon, K.G., Twenty-Five Years, 1892-1916, 2 vols., London: Hodder and Stoughton, 1925.

Hanks, Patrick, Flavia Hodges, A. D. Mills and Adrian Room, The Oxford Names Companion, Oxford: Oxford University Press, 2002

Hussey, Mark, Virginia Woolf A-Z: A Comprehensive Reference for Students, Teachers, and Common Readers to her Life, Work and Critical Reception, Oxford: Oxford University Press, 1996.

Khan, Fahd, Saheel Mukhtar, Ian K. Dickinson, and Seshadri Sriprasad, 'The story of the condom', Indian Journal of Urology (Jan-Mar 2013) 29.1: 12-15, https://www.ncbi.nlm.nih.gov/pmc/articles/PMC3649591/\#ref9; citing Jutte R. Contraception: A history. Cambridge: Polity Press; 2008. [Google Scholar]

King, Julia and Laila Miletic-Vejzovic, The Library of Leonard and Virginia Woolf: A Shorttitle Catalog, by Pullman, WA: Washington State University Press, 2003; http://ntserver1.wsulibs.wsu.edu/masc/onlinebooks/woolflibrary/woolflibraryonline.ht $\mathrm{m}$ 
Kirkpatrick, B.J., and Stuart N. Clarke, A Bibliography of Virginia Woolf, 4th Edition, Oxford: Clarendon Press, 1997.

Maurice-Jones, K. W., The History of Coast Artillery in the British Army, London: Royal Artillery Institution, 1959.

McCree [McCrae], Lieut.-Col. John (1915), 'In Flanders Fields', Punch (8 December), 468. Muscogiuri, Patrizia A., 'Coda: "You, who cross the Channel”: Virginia Woolf, Departures and the Spectro-Aesthetics of Modernism', Cross-Channel Modernisms, ed. Claire Davison, Derek Ryan and Jane Goldman, Edinburgh: Edinburgh University Press, 2020.

Peters, Lawrence, 'Bensusan, Samuel Levy (1872-1958)', Oxford Dictionary of National Biography (23 September 2004) https://doiorg.ezproxy.lib.gla.ac.uk/10.1093/ref:odnb/66987

Schlack, Beverly Ann, Continuing Presences: Virginia Woolf's Use of Literary Allusion, University Park, PA: Pennsylvania State University Press, 1979.

Seabrook, William, Diary of Section VIII, Boston: Thomas Todd, 1917.

Stalla, Heidi, 'Woolf and anti-Semitism: is Jacob Jewish?', in Virginia Woolf in Context, ed. Bryony Randall and Jane Goldman, Cambridge: Cambridge University Press, 2012.

Winter, J. M., 'Britain's “Lost Generation” of the First World War', Population Studies, 31:3 (November, 1977), 449-66.

Wisner, Melissa, 'Geographies of Gender in Jacob's Room: The Smooth Circles of Dods Hill and the Jagged Mounds of the Acropolis', Virginia Woolf Miscellany, 75 (Fall 2009), $16-17$

Woolf, C[ecil]. N. Sidney, Poems, Richmond: Hogarth Press, 1918.

Woolf, Leonard, Beginning Again: An Autobiography of the Years 1911-1918, London: Hogarth Press, 1964. 
Woolf, Virginia, Jacob's Room, London: Hogarth Press, 1922.

Woolf, Virginia, Jacob's Room [1922], ed. Edward L. Bishop, Oxford: the Shakespeare Head by Blackwell, 2004.

Woolf, Virginia, Jacob's Room [1922], ed. David Bradshaw and Stuart N. Clarke, Cambridge: Cambridge University Press, 2020.

Woolf, Virginia, Virginia Woolf's 'Jacob's Room': The Holograph Draft, ed. Edward L. Bishop, New York, NY: Pace University Press, 1998

Woolf, Virginia, Mrs. Dalloway [1925], ed. Anne E. Fernald, Cambridge: Cambridge University Press, 2015.

Woolf, Virginia, To the Lighthouse. London: Hogarth Press, 1927.

Woolf, Virginia, The Years [1937], ed. Anna Snaith, Cambridge: Cambridge University Press, 2014.

Woolf, Virginia, Three Guineas, London: Hogarth Press, 1938.

Woolf, Virginia, The Diary of Virginia Woolf, 5 vols, ed. Anne Olivier Bell and Andrew McNeillie, London: Hogarth, 1979-1985.

Woolf, Virginia, The Letters of Virginia Woolf, ed. Nigel Nicolson and Joanne Trautmann, 6 vols., London: Hogarth, 1975-80.

Woolf, Virginia, The Essays of Virginia Woolf, 6 vols, ed. Andrew McNeillie (vols 1-4) and Stuart N. Clarke (vols 5-6), London: Hogarth, 1986-2011.

Zwerdling, Alex, Virginia Woolf and the Real World, Berkeley, CA: University of California Press, 1986.

\section{NOTES}

\footnotetext{
${ }^{1}$ Woolf, Jacob's Room (London: Hogarth Press, 1922), 253. The forthcoming Cambridge University Press edition of Jacob's Room, edited by David Bradshaw and Stuart N. Clarke, follows the same pagination.

${ }^{2}$ See Bishop, 'Mind the Gap'; and Bishop's edition of Jacob's Room (

${ }^{3}$ See Bradshaw, "'Vanished Like Leaves'; Bradshaw, Winking Buzzing Carpet-Beating.
} 


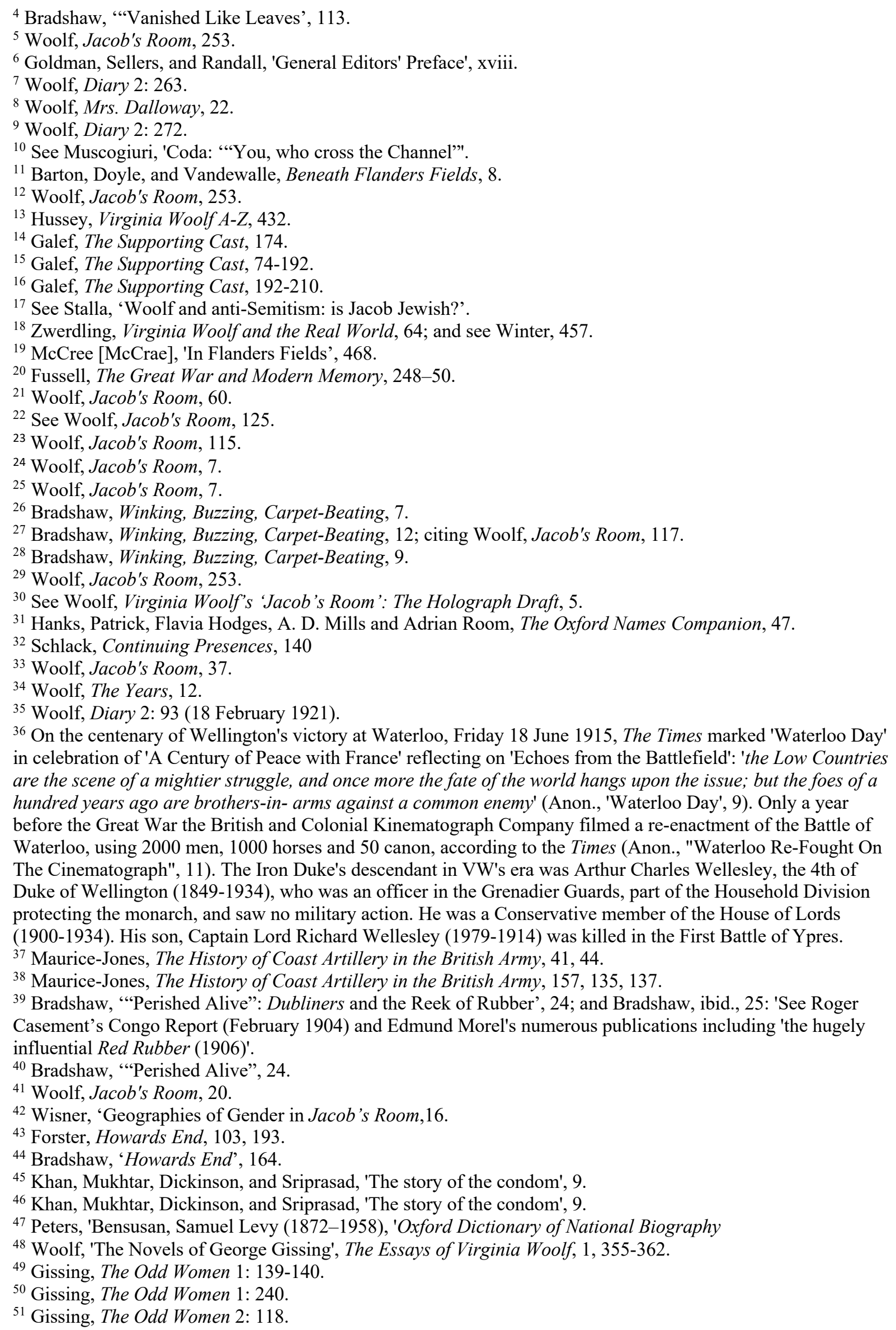


${ }^{52}$ Bradshaw, Winking, Buzzing, Carpet-Beating, 9; citing Woolf, Jacob's Room, 21.

${ }^{53}$ Woolf, Virginia Woolf's 'Jacob's Room': The Holograph Draft, 5.

${ }^{54}$ King and Miletic-Vejzovic, The Library of Leonard and Virginia Woolf, 199.

${ }^{55}$ Anon, 'Seabrook', 10.

${ }^{56}$ Anon, 'Seabrook Motor Lorries', 4

${ }^{57}$ Anon, 'Clifford', 5.

${ }^{58}$ Bishop, 'Mind the Gap', 41.

${ }^{59}$ Woolf, Jacob's Room, 287-288)

${ }^{60}$ Bishop, 'Mind the Gap', 41.

${ }^{61}$ The first edition of Jacob's Room was published by the Hogarth Press on 27 October 1922; the first American edition by Harcourt Brace on 8 February 1923. See Kirkpatrick and Clarke, A Bibliography of Virginia Woolf, 27-29. Both the Shakespeare Head and Cambridge editions honour the gaps of the English first edition, but the Textual Apparatus of each records the American closures. Compare Anne Fernald's Cambridge edition of Mrs Dalloway which for the first time clearly points up all of Woolf's original gaps which are significantly different in number between English and American editions, simultaneously published on 14 May 1925.

${ }^{62}$ Grey, Twenty-Five Years, 20.

${ }^{63}$ Bradshaw, Winking, Buzzing, Carpet-Beating, 15.

${ }^{64}$ Woolf, 'Heard on the Downs' (1916), Essays 2: 40-42.

${ }^{65}$ Muscogiuri, 'Coda: "'You, who cross the Channel”".

${ }^{66}$ Muscogiuri, 'Coda: “'You, who cross the Channel”'.

${ }^{67}$ Woolf, Three Guineas, 197.

${ }^{68}$ Woolf, Jacob's Room, 140.

${ }^{69}$ Stalla, 'Woolf and anti-Semitism: is Jacob Jewish?'.

${ }^{70}$ L.Woolf, Beginning Again, 181.

${ }^{71}$ Darling, 20th Hussars in the Great War, 86.

${ }^{72}$ Woolf, Diary 1: 16.

${ }^{73}$ Woolf, Diary 1: 34

${ }^{74}$ L.Woolf, Beginning Again, 182-3.

${ }^{75}$ Woolf, Letters 2: 209.

${ }^{76}$ L.Woolf, Beginning Again, 181.

${ }^{77}$ Woolf, Letters 2: 209.

${ }^{78}$ Woolf, Letters 2: 225.

${ }^{79}$ Woolf, Diary 1: 123.

${ }^{80}$ Woolf, Diary 1: 124.

${ }^{81}$ [Child], 'Four Young Poets', 40.

82 [Child], 'Four Young Poets', 40.

83 [Child], 'Four Young Poets', 40.

${ }^{84}$ Bradshaw, Winking, Buzzing, Carpet-Beating, 27.

${ }^{85}$ Bradshaw, Winking, Buzzing, Carpet-Beating, 26.

${ }^{86}$ Woolf, Jacob's Room, 233, 234.

${ }^{87}$ Bradshaw, Winking, Buzzing, Carpet-Beating, 27.

${ }^{88}$ Bradshaw, Winking, Buzzing, Carpet-Beating, 27.

${ }^{89}$ Bradshaw, "'Vanished Like Leaves', 107.

${ }^{90}$ Woolf, Jacob's Room, 290.

${ }^{91}$ [Child], 'Four Young Poets', 40; citing Cecil Woolf, Poems.

${ }^{92}$ Woolf, Jacob's Room, 290.

${ }^{93}$ Woolf, Jacob's Room, 8, 9.

${ }^{94}$ Goldman, "'Her-it-age!", 3.

${ }^{95}$ Woolf, To the Lighthouse, 286. 